\title{
Characterizations of Size-segregated Ultrafine Particles in Diesel Exhaust
}

Aerosol and Air Quality Research

\author{
Jaehyun Lim, Cheolsoo Lim, Sungwoon Jung*
}

Division of Global Environment Research, Department of Climate and Air Quality Research, National Institute of Environmental Research, Incheon 22689, Korea

\section{ABSTRACT}

Size-segregated ultrafine particles (UFPs) in diesel exhaust were investigated to characterize carbonaceous substances, metals, and organic compounds originating from a medium-duty diesel engine dynamometer using the 13 driving mode. Organic carbon (OC) and elemental carbon (EC) peaked at 330-550 nm, but the OC/EC ratio showed two peaks in the ultrafine and accumulation modes. The distribution trend of metal elements was opposite to that of the sizesegregated OC/EC ratio. The amounts of toxic $\mathrm{Pb}, \mathrm{As}$, and $\mathrm{Cd}$ were less than $0.03-2.5 \%$ in diesel exhaust particles (DEPs), but their cumulative fractions in the ultrafine mode exceeded $50 \%$. Most organic compounds (76.6\%) and alkanes (67.0\%) were emitted in the accumulation mode (170-1000 nm). More than $70 \%$ of the identified polycyclic aromatic hydrocarbons (PAHs) were emitted in the accumulation mode $(94-1000 \mathrm{~nm})$, with phenanthrene being the most abundant. Two significant size ranges of toxicity equivalent quantity peaks in the ultrafine (34-66 nm) and accumulation (170-330 nm) modes were observed for the size-segregated DEPs. Contrary to the trends for PAHs and organic compounds, the identifiable nitrogen-containing polycyclic aromatic compounds were more abundant in the ultrafine mode. Overall toxicity was high as UFPs can be deposited with high efficiency throughout the human respiratory tract.

Keywords: Diesel exhaust particles, Organic carbon, Elemental carbon, Metal elements, Polycyclic aromatic hydrocarbons, Nitrogen-containing polycyclic aromatic compounds, Toxicity

\section{INTRODUCTION}

Due to the better power torque (Kontses et al., 2020) and less fuel consumption versus gasoline vehicles (Du et al., 2015), the increasing number of diesel vehicles are reported (European Automobile Manufacturer's Association, 2015). However, the increasing population of on-road diesel vehicles have caused adverse effect of air quality (Banerjee and Christian, 2019; Onay et al., 2019), climate change (Lund et al., 2014) and human health (Kuo et al., 2013; Snow et al., 2014; Yang et al., 2019). Even though diesel particulate filter (DPF) and selective catalytic reduction (SCR) system can contribute less mass concentration of diesel exhaust particles (DEPs) (Jiang et al., 2018), the number concentration of ultrafine particles (UFPs) including less than $100 \mathrm{~nm}$ diameter may not be reduced from tailpipe (Liati et al., 2014; Ni et al., 2018; Banerjee et al., 2019). This could cause serious cardiovascular diseases and lung cancer because higher UPFs number concentration of DEPs can attribute larger surface area for the transport, and adsorption of emitted hazardous materials from diesel vehicles (Li et al., 2010; Zhang et al., 2018).

Metal species in collected airborne particulate matter (PM) from the roadway, traffic emissions and urban areas can induce reactive oxygen species (ROS) generation, which can promote oxidative stress and human inflammatory response in the pulmonary and cardiovascular system (Magnani et al., 2016; Shuster-Meiseles et al., 2016; Moretti et al., 2019). A municipal waste incinerator (Xu et al., 2020), coal-fired power plants (Oetari et al., 2019), and biomass burning (Ahmed et al., 2016) are responsible for emitted metal species in airborne particles as anthropogenic sources. In addition to these, fossil fuel vehicles are significant sources of metal-bounded particle 
emissions and one of the most crucial components are DEPs (Chuang et al., 2012; Golokhvast et al., 2015; Li et al., 2018).

Zhang et al. (2018) reported that the formation of self-nucleated new particles and the surface area of the soot particles could influence the organic carbon (OC) concentration of the DEPs, which is also controlled by the abundance of surface sites for adsorption of organic species. In addition to this, the value of the organic carbon/elemental carbon ratio was used to determine the source and harmful components of the particulate matter (Yang et al., 2019; Zhou et al., 2019).

In particular, Wang et al. (2003) reported that diesel vehicles can emitted 220 and 10 times concentrations of metals compared to electrical arc furnaces and coke ovens, respectively. However, currently there are no regulations for metal elements in DEPs (Yang et al., 2019) and it becomes challenging to differentiate between metal compounds from gasoline and diesel vehicles because of no more usage of leaded gasoline (Zheng et al., 2004).

Several studies on dynamometer tests have been conducted to characterize metal elements in DEPs (Oanh et al., 2010; Chiang et al., 2012; Wu et al., 2016; Yang et al., 2019). Yang et al. (2019) tested gasoline vehicles and light-duty diesel vehicles using chassis dynamometer system, and heavy-duty diesel vehicles with engine dynamometer operating under the New European Driving Cycle (NDEC) (DiselNet, 2019a) and U.S. EPA FTP transient cycle procedure (DiselNet, 2019b), respectively. Based on $\mathrm{PM}_{2.5}$ samples, the average emission factor of metal species in DEPs $\left(225 \mu \mathrm{g} \mathrm{km}^{-1}\right)$ was more than two times of that for gasoline vehicles $\left(106 \mu \mathrm{g} \mathrm{km}^{-1}\right)($ Yang et al., 2019). Engine dynamometer measurements under two different engine speeds and loadings demonstrated that the metals content in DEPs generally increased with an increase in engine load (Lim et al., 2009). In case of light- duty diesel trucks without after-treatment, high driving condition ( $>60 \mathrm{~km} \mathrm{~h}^{-1}$ ) showed $55 \%$ decreased metal elements compared to low driving condition (20-30 $\mathrm{km} \mathrm{h}^{-1}$ ) (Wu et al., 2016). Several studies (Geller et al., 2006; Liati et al., 2018) reported that the emitted $\mathrm{Fe}, \mathrm{Cr}$, and $\mathrm{Ti}$ concentration in diesel exhaust could be higher than same metal species from gasoline vehicle. Based on other studies (Hao et al., 2019; Yang et al., 2019), fuels, lubricants and the engine wear are main sources of metal emissions from vehicles. Interestingly, biodiesel fuel mixed with $20 \%$ of mineral diesel increased emissions of some metal contents; for instance $\mathrm{Fe}, \mathrm{Cr}, \mathrm{Ni}, \mathrm{Zn}$, and $\mathrm{Mg}$, which indicating that alternative fuel could contribute on more emissions of some metal contents in DEPs (Dwivedi et al., 2006).

Higher oxidative stress and cytotoxicity can be caused by organics in DEPs compared to fine particulate matter in urban sampling sites (Catino et al., 2017; Zhang et al., 2018). Organic species in DEPs could promote ROS generation (Pan et al., 2004; Lee et al., 2020), which are impervious to acid and solvent extraction, implying the intrinsic toxicity of DEPs. In addition, a higher loading of diesel vehicles showed more emissions of polycyclic aromatic compounds (PAHs) (Lim et al., 2015), revealing more relationship with endocrine disruption (Pěnčíková et al., 2019). Moreover, around 8-18 times of PAHs and n-alkanes, which are potential carcinogens (Wang et al., 2019), are emitted from heavy-duty diesel vehicles under creep operation conditions compared to cruise modes (Shah et al., 2005). This exhibited that specific driving conditions can significantly contribute on emissions of organic compounds with respect to the amounts and compositions from diesel vehicles (Lim et al., 2015). More data are needed for legislation of unregulated species, such as organic compounds and metal elements from diesel vehicles even though particle mass concentrations and total hydrocarbons in DEPs are already included in standards and regulations in many countries (Reijnders et al., 2018).

Many researchers (Lim et al., 2015; Tan et al., 2017; Zhang et al., 2018; Jung et al., 2019; Zhou et al., 2019) studied on characterizing PAHs and aliphatic compounds in DEPs. Diesel engines generate 100-320 nm particle size of PAHs under creep and idle driving conditions (Riddle et al., 2007). Zielinska et al. (2004a) and Zhou et al. (2019) tested the effects of operation conditions of diesel engines on exhaust particles. More PAHs of smaller molecular weights and fine particles (100-180 nm) were emitted under low engine loads conditions. However, other study (Lim et al., 2015) showed that more PAHs of heavier molecular weights and larger size $(94-1000 \mathrm{~nm})$ were observed during high speed and engine load condition. Even though the emission of gasoline vehicles includes more PAHs of heavier molecular weights, and diesel vehicles emitted more nitrogen-containing polycyclic aromatic compounds (Cao et al., 2017; Lin et al., 2019; Zhao et al., 2020), distinguishing emitted species from gasoline- versus diesel-powered vehicles according to identification of organic compounds remains unexplored. 
Thus, there is an urgent need to investigate both the chemical and physical properties of DEPs depending on the driving conditions and use the results to properly evaluate the efficiencies of mitigation devices. In doing so, direct and simple approaches to control and mitigate harmful emissions from diesel vehicles can be explored. In this study, a medium-duty diesel engine and the 13-mode test were evaluated to characterize size segregation of metal elements, organic species, and carbonaceous substances in DEPs.

\section{MATERIALS AND METHODS}

\subsection{Sampling and Measurements}

The setups and procedures used for monitoring and sampling the DEPs in this study are provided in detail other studies (Lim et al., 2008, 2009, 2015) and in the supplementary data (Fig. S1). In brief, a medium-duty diesel engine, the most commonly operating diesel vehicle engine in Korea, was tested using a dynamometer (APA DYNO, AVL Co., Austria). The driving conditions consisted of the 13-mode test (DieselNET, 2019c), which requires that a specific engine speed and load be achieved in $1000 \mathrm{~s}$. Because the driving conditions are intended to regulate emitted diesel exhaust, this test sufficiently simulates on-road driving conditions. The subsequent analyses and tests focus on evaluation of the most frequent on-road driving patterns in Korea.

Fig. S2 exhibits the 13-mode driving conditions as a function of engine speed ( $\mathrm{rpm}$ ) and engine load (\%) along the secondary and primary $y$-axes with the corresponding elapsed time ( $x$-axis), respectively. The following 13 individual modes are shown in driving time sequence: (1) $83 \mathrm{~s}$ (for cold idle), (2) $80 \mathrm{~s}$ (for $1800 \mathrm{rpm} / 10 \%$ ), (3) $80 \mathrm{~s}$ (for $1800 \mathrm{rpm} / 25 \%$ ), (4) $80 \mathrm{~s}$ (for $1800 \mathrm{rpm} / 50 \%$ ), (5) $80 \mathrm{~s}$ (for $1800 \mathrm{rpm} / 75 \%$ ), (6) $250 \mathrm{~s}$ (for $1800 \mathrm{rpm} / 100 \%),(7) 84 \mathrm{~s}$ (for warm idle-1), (8) $100 \mathrm{~s}$ (for $3000 \mathrm{rpm} / 100 \%$ ), (9) $20 \mathrm{~s}$ (for $3000 \mathrm{rpm} / 75 \%$ ), (10) $20 \mathrm{~s}$ (for $3000 \mathrm{rpm} / 50 \%$ ), (11) $40 \mathrm{~s}$ (for $3000 \mathrm{rpm} / 25 \%$ ), (12) $20 \mathrm{~s}$ (for $3000 \mathrm{rpm} / 10 \%$ ), and (13) $83 \mathrm{~s}$ (for final warm idle-2).

The specific information, such as sulfur content of $0.02 \%$ (by wt.), specific gravity of $830 \mathrm{~kg} \mathrm{~m}^{-3}$ $\left(15^{\circ} \mathrm{C}\right)$, cetane number of 56 , and $10 \%$ distillation residue of $0.01 \%$ (ash content, by wt.), of the diesel fuel for this study also have been demonstrated in other study (Lim et al., 2009).

The residence time of emitted diesel particles from engine outlet to points of collection and monitoring was approximately $3 \mathrm{~s}$. Alongside monitoring the particle size distributions and particle number concentrations using a scanning mobility particle sizer (SMPS, TSI 3936, TSI Inc., MN, USA), the DEPs were sampled in a low-pressure impactor (LPI) (similar to Hauke Aeras 25-4/0.015, Finland) at a flow rate of $25 \mathrm{~L} \mathrm{~min}^{-1}$ followed by isokinetic sampling port directed exhaust through an ejector diluter (Dekati Ltd.) with pressurized air supplier (Fig. S1). The DEPs were segregated into 6 size groups with individual cut-off sizes of 34, 66, 94, 170, 330, and $550 \mathrm{~nm}$ for following gravimetric measurements and chemical analyses. As described in previous studies (Lim et al., 2009, 2015), the DEPs were collected on two types of $70 \mathrm{~mm}$ (Teflon-coated glass fiber and quartz) filters for chemical speciation. To correct positive artifacts on quartz filters (Whatman) (Yang et al., 2007), DEPs were collected onto Teflon-coated glass fiber filters (Emfab, Pallflex), and metal elements as well as organic species were analyzed. Including the blank ones, all the filter samples were stored at $-25^{\circ} \mathrm{C}$ in the dark before the chemical analyses.

\subsection{Analysis of Elemental/Organic Carbon and Metals Content in DEPs}

To measure extractable total carbon (TC), half of collected quartz filter samples underwent solvent extraction using tetrahydrofuran (THF) (Merck, Germany) followed by dichloromethane (DCM) (Merck, Germany) and hexane (Merck, Germany). The extract was then transferred into a pre-cleaned and pre-weighed tin cup to evaporate solvents using a gentle nitrogen flow before CHNS measurements (Perkin Elmer 2400 series II analyzer, Shelton, USA). Cystine (Micro Analysis Limited, Devon, UK) was used to establish a calibration curve of carbon analyses. Replicate cystine standards were also tested between analyses to ensure accuracy and consistency of the calibration. The remaining half of the quartz filter samples was put into a $340^{\circ} \mathrm{C}$ furnace for two hours to remove organic carbon (OC) before solvent extraction. By applying the same CHNS measurements, extractable elemental carbons (EC) of the solvent extracts were obtained. Extractable OC was derived as difference between the extractable TC and EC.

The inductively coupled plasma-mass spectrometer (ICP-MS, PerkinElmer Sciex Elan 6100, 
USA) with dual detector mode (pulse and analog counts) was used for triplicate analysis of the metal elements in the DEPs. To reduce background interference $\left({ }^{40} \mathrm{Ar}^{16} \mathrm{O}^{+}\right)$, the cold plasma (pulse detector mode) was conducted for measuring iron content. ICP-individual standard solutions (Merck, Germany) and multi element standard solutions VI (Merck, Germany) were employed to establish calibration curves of 17 standard metals, such as silver (Ag), arsenic (As), beryllium (Be), cadmium (Cd), cobalt (Co), cesium (Cs), copper (Cu), iron (Fe), indium (In), lithium (Li), manganese $(\mathrm{Mn})$, molybdenum (Mo), nickel $(\mathrm{Ni})$, lead $(\mathrm{Pb})$, tin $(\mathrm{Sn})$, thallium $(\mathrm{TI})$, and vanadium $(\mathrm{V})$ in five concentrations $\left(1,10,20,50\right.$, and $\left.100 \mu \mathrm{g} \mathrm{L}^{-1}\right)$. The blank values of $0.001-0.002 \mathrm{ng} \mathrm{m}^{-3}$ were subtracted from the sample values and the minimum detection limit (MDL) were within the ranges of $0.001-0.138 \mathrm{ng} \mathrm{m}^{-3}$ for the metal elements. The detailed experimental methods for the elemental/organic carbon and metals content in the DEPs are provided in a previous study (Lim et al., 2008 and 2009).

\subsection{Analysis of Organic Compounds in the DEPs}

Organic compounds were analyzed using a gas chromatography-mass spectrometry (GC-MS) HP-5MS column ( $5 \%$ phenyl-methylpolysiloxane capillary column, $30 \mathrm{~m} \times 0.25 \mathrm{~mm}$ i.d. $\times 0.25 \mu \mathrm{m}$, Agilent Technologies, CA, USA) with helium as the carrier gas at a flow rate of $1 \mathrm{~mL} \mathrm{~min}^{-1}$. The initial temperature was $60^{\circ} \mathrm{C}$ for $3 \mathrm{~min}$ and it was increased to $280^{\circ} \mathrm{C}$ at a rate of $8^{\circ} \mathrm{C} \mathrm{min} \mathrm{m}^{-1}$. The final oven temperature $\left(280^{\circ} \mathrm{C}\right)$ was held for $15 \mathrm{~min}$. Spectrum references based on the National Institute of Standards and Technology mass spectral library, or comparison with mass fragmentation patterns and elution times of the authentic standards were conducted to identify individual compounds. With regard to quality analysis and quality control, the identifiable organic compounds were quantified taking into consideration the extraction recovery efficiencies and responses of the co-injection standards. Background interference was examined by conducting blank analyses and $7-13 \%$ of propagated errors were resulted. Selected ion monitoring (SIM) was selected to improve the detection sensitivities of the PAHs in the extracts during the separated GC-MS analyses. A suite of 16 priority standards (Supelco, PA, USA) recommended by the US EPA was employed to identify the PAHs in the extract samples.

An HP-5MS capillary column in a GC (Shimadzu, Japan) coupled with dual detectors, such as a flame-ionization detector (FID, Shimadzu, Japan), and a chemiluminescence detector (Antek Inc., TX, USA), was used to separate nitrogen-containing organic compounds. The temperature program of the GC-MS measurements was employed at a constant flow rate of the carrier gas using helium $\left(3 \mathrm{~mL} \mathrm{~min}^{-1}\right)$. The organic species were carried to a 10:1 split adaptor at the end of the separation column, and introduced to the FID and chemiluminescence detector. To pyrolyze and quantify the amounts of nitrogen-containing compounds, operation temperature of the chemiluminescence detector was set at $950^{\circ} \mathrm{C}$. The blank values of $0.002-0.003 \mathrm{ng} \mathrm{m}^{-3}$ were subtracted from the sample values and the minimum detection limit (MDL) were within the ranges of $0.002-0.924 \mathrm{ng} \mathrm{m}^{-3}$ for the organic compounds. The details of the experimental procedures for the organic compounds are available elsewhere (Lim et al., 2015).

\section{RESULTS AND DISCUSSION}

\subsection{Size-segregated Elemental Carbon, Organic Carbon, and Metals in DEPs}

According to previous study (Lim et al., 2009) on steady-state mode tests using diesel engine dynamometer, it is notable that the particle size ranges of $94-170 \mathrm{~nm}$ and $170-330 \mathrm{~nm}$ showed peak concentrations of elemental carbon under a full engine load with medium (1800 rpm) and maximum (3000 rpm) speeds, respectively. Interestingly, the size ranges of $170-330 \mathrm{~nm}$ also exhibited the highest concentration of elemental carbon in Fig. 1 similar like the first phase of the previous research (Lim et al., 2009).

The peaks for both elemental carbon and organic carbon occurred for the same size range $(330-550 \mathrm{~nm})$. The corresponding ultrafine size ranges (below $100 \mathrm{~nm}$ ) and larger size ranges (above $100 \mathrm{~nm}$ ) of the elemental carbon and organic carbon fractions in the above-mentioned six size ranges were within $7.5-14.7 \%$ and $14.8-27.7 \%$, respectively. Our observations suggest that most of the particles were emitted from the diesel engine in the accumulation mode (above $100 \mathrm{~nm}$ ), accounting for $80.9 \%$ of EC and $82.3 \%$ of OC. This finding could be attributed to the 


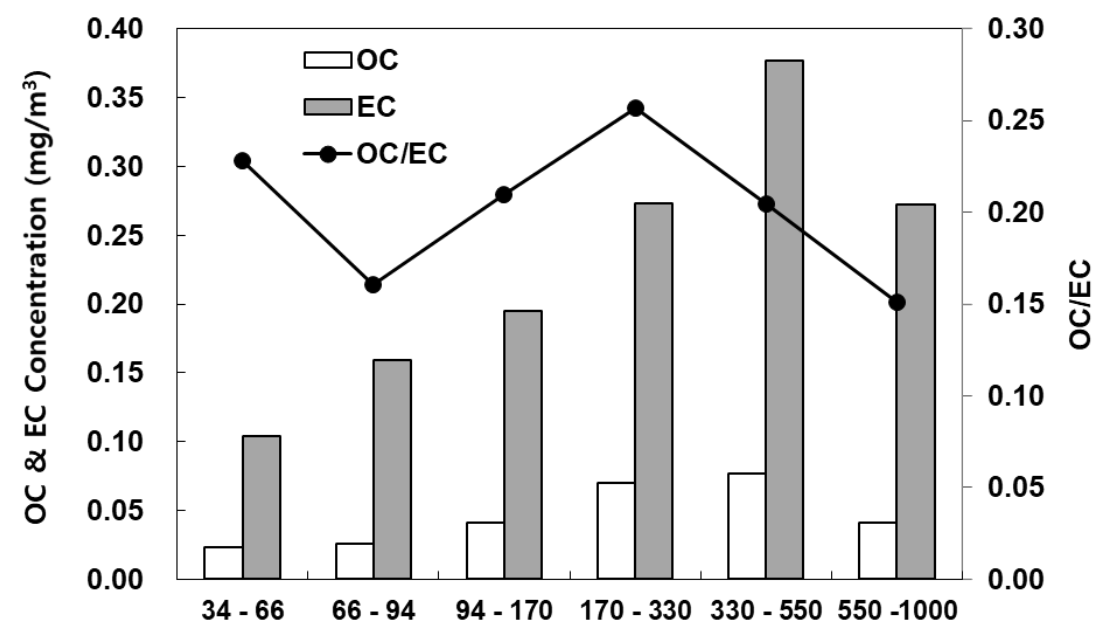

Size range of individual LPI stages $(\mathrm{nm})$

Fig. 1. Size distribution of OC, EC, and OC-EC ratios of DEPs (34-1000 nm). All data points represent an average of triplicate measurements with a standard deviation of $0.01-0.1 \mathrm{mg} \mathrm{m}^{-3}$ for OC and $0.01-0.15 \mathrm{mg} \mathrm{m}^{-3}$ for EC.

effect of a higher engine load portion in the 13-mode driving condition, which resulted in shifting the EC and OC peak concentrations toward a larger-size range in the accumulation mode (Li et al., 2014; Zhang et al., 2015). The size ranges of $34-66 \mathrm{~nm}$ and $170-330 \mathrm{~nm}$ demonstrated for the $\mathrm{OC} / \mathrm{EC}$ ratio peaks, respectively in Fig. 1 . The first peak value of the OC/EC ratio was 0.23 in the $34-66 \mathrm{~nm}$ ultrafine size range, and the second peak value of the OC/EC ratio was 0.26 in the $170-$ $330 \mathrm{~nm}$ accumulation size range. Consequently, two different size range of emissions were observed from different particle-bound $O C$ fractions in this study. The smaller particles were emitted during the idle for the ultrafine mode. Moreover, low loading condition demonstrated a comparatively larger surface per mass ratio, leading to the adsorption of semi-volatile and volatile organic compounds onto smaller particles (Zhang et al., 2018). This adsorption could contribute to the smaller particles leading to higher OC fractions and OC/EC ratios, as observed in this study. Interestingly, the second peak of the OC/EC ratio could be attributed to higher unburned hydrocarbon emissions and lubricating oil consumption under a full engine load, and the fact that the $\mathrm{OC}$ was adsorbed on the accumulation mode particles (Zhou et al., 2019). In addition, emitted semi-volatile and volatile organic compounds originate from unburned fuels, lubricants and combustion byproducts oxidation as part of the OC fraction (Schneider et al., 2005; Zhang et al., 2018).

The relationship between carbonaceous materials and metals in the diesel exhaust particles can be examined using Fig. 2, which shows the $\mathrm{EC}, \mathrm{OC}$, and metals concentrations in six size range from 34-1000 nm.

Interestingly, almost $40 \%$ of the metals in the DEPs were emitted in the ultrafine mode (size range $34-94 \mathrm{~nm}$ ) and $21 \%$ of the metals showed a peak range of $66-94 \mathrm{~nm}$. It is noteworthy that the metals showed a trend opposite to that of the EC and OC concentrations (Fig. 2), except for the size range 550-1000 nm; when the metal contents increased (decreased) in individual size ranges, the $\mathrm{EC}$ and $\mathrm{OC}$ concentrations decreased (increased) concurrently. This finding is similar to that of other studies (Kim et al., 2005; Lim et al., 2009), which indicated that the usage of metal additives in diesel fuel could restrain both growth and inception of soot, because metals can catalyze oxidation of soot in combustion chambers. More significant oxidation was conducted by iron-doped soot at combustion temperatures above $500^{\circ} \mathrm{C}$, and "shrank" to become nano-sized (Kim et al., 2005). Therefore, the larger amount of metals in the ultrafine DEPs (as shown in Fig. 2) could have been catalyzed by oxidation of larger size of DEPs including nucleation at high temperatures under $100 \%$ load (Lim et al., 2009). Moreover, Rönkkö et al. (2014) reported that diesel vehicles can emit a substantial number of nano- and ultrafine-sized non-volatile particles, accounting for up to $20-30 \%$ of the total particle number concentration, and these particles can contain metals from the lubricant oil. 


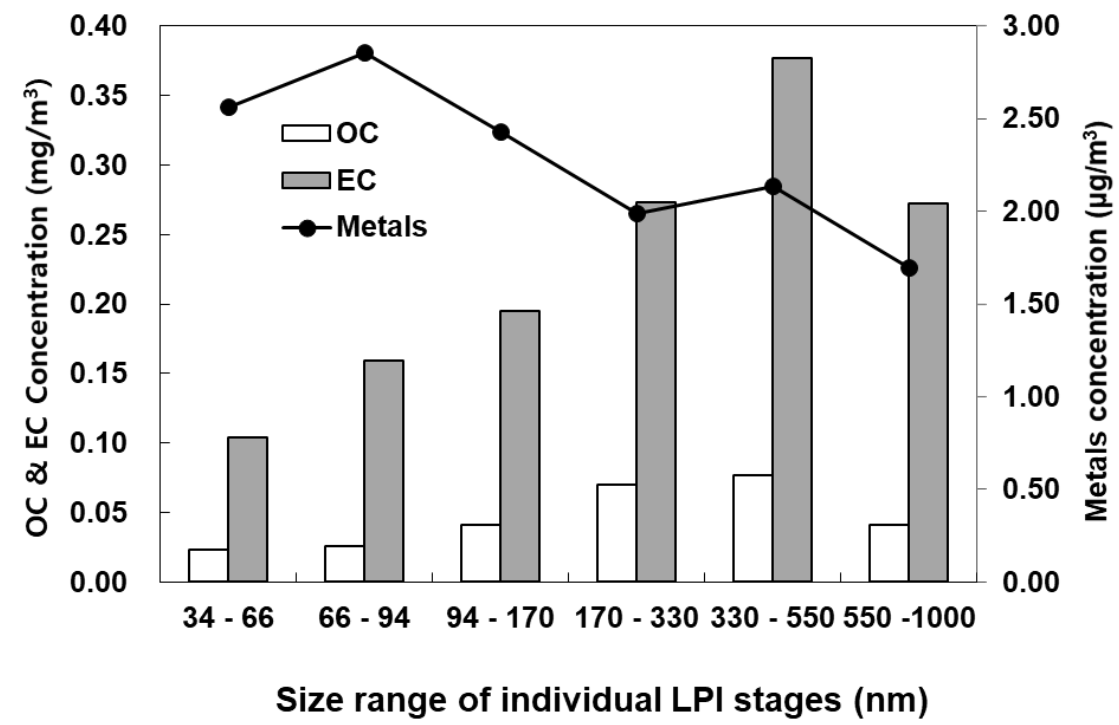

Fig. 2. Size distribution of OC, EC and metals in DEPs. All data points represent an average of triplicate measurements with a standard deviation of $0.01-0.1 \mathrm{mg} \mathrm{m}^{-3}$ for $\mathrm{OC}, 0.01-0.15 \mathrm{mg} \mathrm{m}^{-3}$ for EC and 0.21-0.33 $\mu \mathrm{g} \mathrm{m}^{-3}$ for metals.

Even though the rate of lubricant consumption $\left(<60 \mathrm{~g} \mathrm{~h}^{-1}\right)$ relative to that of diesel fuel consumption (10-27 $\mathrm{kg} \mathrm{h}^{-1}$ ) was smaller during the 13-mode test, the lubricant contained a quantified metals concentration of $43.9 \mu \mathrm{g} \mathrm{mL}^{-1}$, which was more than twice as high as that in the diesel fuel $\left(20.3 \mu \mathrm{g} \mathrm{mL}^{-1}\right)$ used in this study. Notably, Fe was the major component in the tested diesel fuel and lubricant according to a previous study (Lim et al., 2009), and as shown in Fig. S3, the 13-mode test consistently exhibited the highest Fe emissions, ranging from 57-66\% of the total metal content in the DEPs (34-1000 nm). Liati et al. (2018) also reported that Febearing ash particles were significantly more abundant from diesel vehicles than gasoline ones based on transmission electron microscopy images of ultrafine soot particles. Interestingly, although $\mathrm{Pb}, \mathrm{As}$, and $\mathrm{Cd}$ comprised less than $2.5 \%\left(9.5-110.2 \mathrm{ng} \mathrm{m}^{-3}\right), 0.27 \%\left(0.9-10.6 \mathrm{ng} \mathrm{m}^{-3}\right)$, and $0.03 \%\left(0.3-1.2 \mathrm{ng} \mathrm{m}^{-3}\right)$ of the of the total quantified metals in this study, they are of concern because of the possibility of adverse effects on human health and the environment (Catino et al., 2017) (Fig. 3).

Similar to the quantified metals including Fe in Fig. S3, more $\mathrm{Pb}$, As, and $\mathrm{Cd}$ were emitted in the ultrafine size ranges, showing peak ranges of 66-94 $\mathrm{nm}$. In addition, the cumulative fractions of $\mathrm{Pb}, \mathrm{As}$, and $\mathrm{Cd}$ for the ultrafine mode (34-94 $\mathrm{nm}$ ) were 57\%, 56\%, and 50\%, respectively, in Fig. 3. Due to nano-sized particles are easy to permeate the respiratory system (Ruckerl et al., 2011; Bakand et al., 2012), a decrease in ultrafine metals emissions from diesel vehicles can prevent inhalation of hazardous smaller DEPs. Thus, it may be worth note to study on $\mathrm{Pb}, \mathrm{As}$, and $\mathrm{Cd}$ in diesel exhaust for setting emission standards of metal-induced particles, especially in urban areas with a high number of diesel-powered vehicles (Lim et al., 2009).

\subsection{Size-segregated Organics, PAHs, and Nitrogen-containing Polycyclic Aromatic Compounds in DEPs}

As shown in Fig. 4, alkanes (C13-C31) emitted from the transition driving mode test constituted the most abundant identifiable organic compound in the DEPs $(<1 \mu \mathrm{m})$, exhibiting a peak range of 330-550 $\mathrm{nm}$.

Most organic compounds were emitted from the diesel engine in the accumulation mode, accounting for $76.6 \%$ and $67.0 \%$ of total organics and alkanes, respectively. Similar to the results for the EC and OC in this study, the higher fuel consumption, higher temperature, higher pressure, and higher FTA (fuel to air) ratio at higher engine loads (Lim et al., 2015; Zhang et al., 2015) may also be responsible for the variations in the organics and alkanes contents in the accumulation mode (size range 170-1000 nm). Interestingly, alkanes (C9-C24) were the major component in 

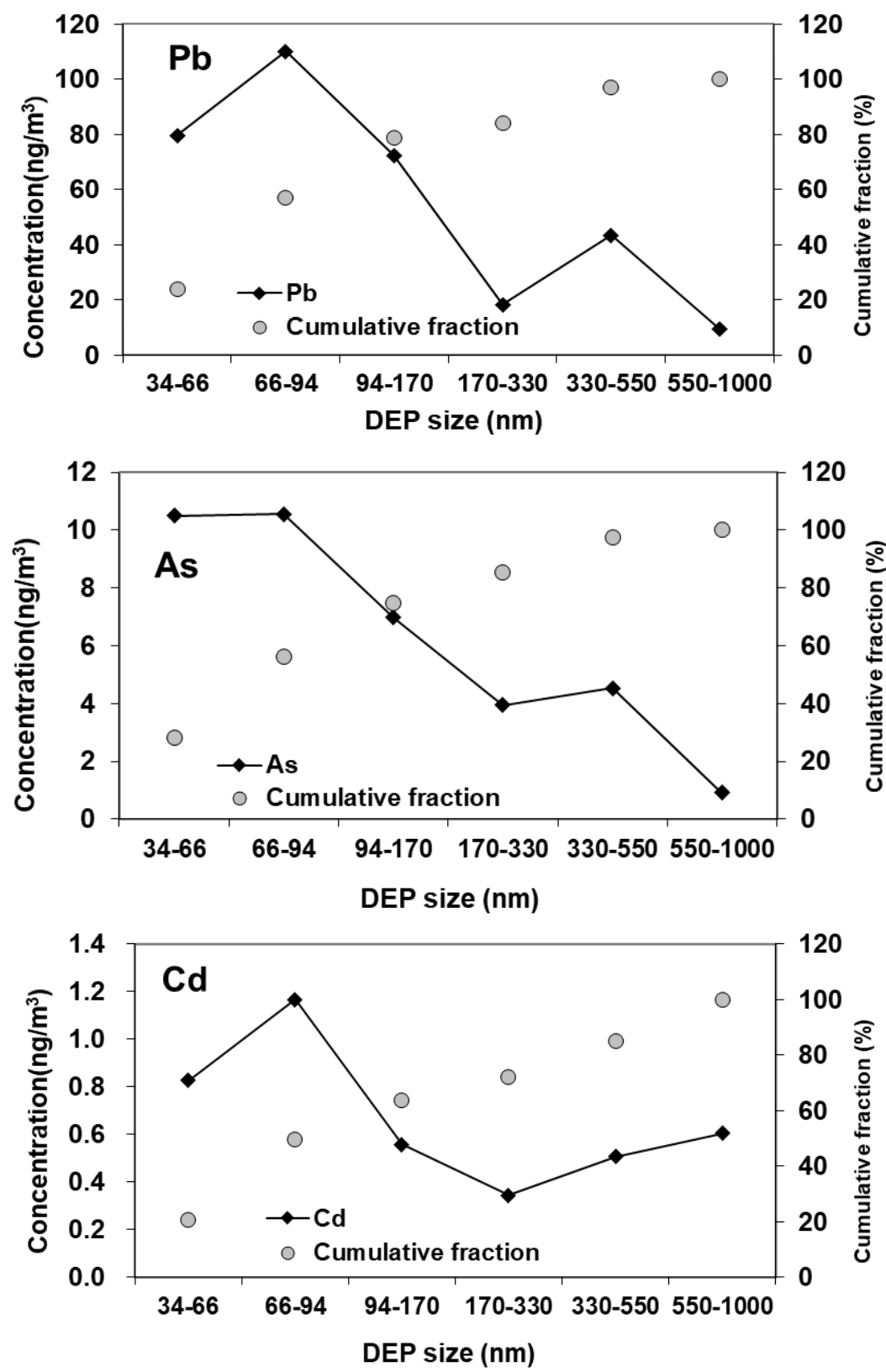

Fig. 3. Size distribution and cumulative fractions of $\mathrm{Pb}, \mathrm{As}$ and $\mathrm{Cd}$ in $\mathrm{DEPs}$. All data points represent an average of triplicate measurements with a standard deviation of $0.005-0.168 \mathrm{ng} \mathrm{m}^{-3}$ for $\mathrm{Pb}$, 0.004-0.037 $\mathrm{ng} \mathrm{m}^{-3}$ for As and 0.001-0.009 $\mathrm{ng} \mathrm{m}^{-3}$ for $\mathrm{Cd}$.

the tested diesel fuel in a previous study (Lim et al., 2015), and as shown in Fig. 4, the transition driving condition consistently exhibited the highest alkanes concentration, ranging from $56-88 \%$ of the size-segregated organics in the DEPs. In addition, the relationship between organic compounds and metals in the DEPs demonstrated a result similar to that of carbonaceous materials (OC and EC) versus metals due to the catalyzing oxidation of soot and organic compounds by metals in the combustion chamber (Kim et al., 2005; Lim et al., 2009) (Fig. 4).

Fig. 5 and Table S1 depict 10 identified PAHs in the size-segregated DEPs according to their molecular weights: acenaphthylene (Acy), acenaphthene (Ace), fluorene (Flu), phenanthrene (Phe), anthracene (Ant), fluoranthene (Flt), pyrene (Pyr), benzo(a)anthracene (BaA), benzo(k)fluoranthene (BkFt), and benzo(a)pyrene (BaP). The total concentrations of the PAHs ranged from 1.1-67.9 $\mathrm{ng} \mathrm{m}^{-3}$.

More than $70 \%$ of the PAHs in the DEPs were emitted in the accumulation mode (size range 94-1000 nm), and 23\% of the PAHs showed peak ranges of $170-330 \mathrm{~nm}$. Same as the size 


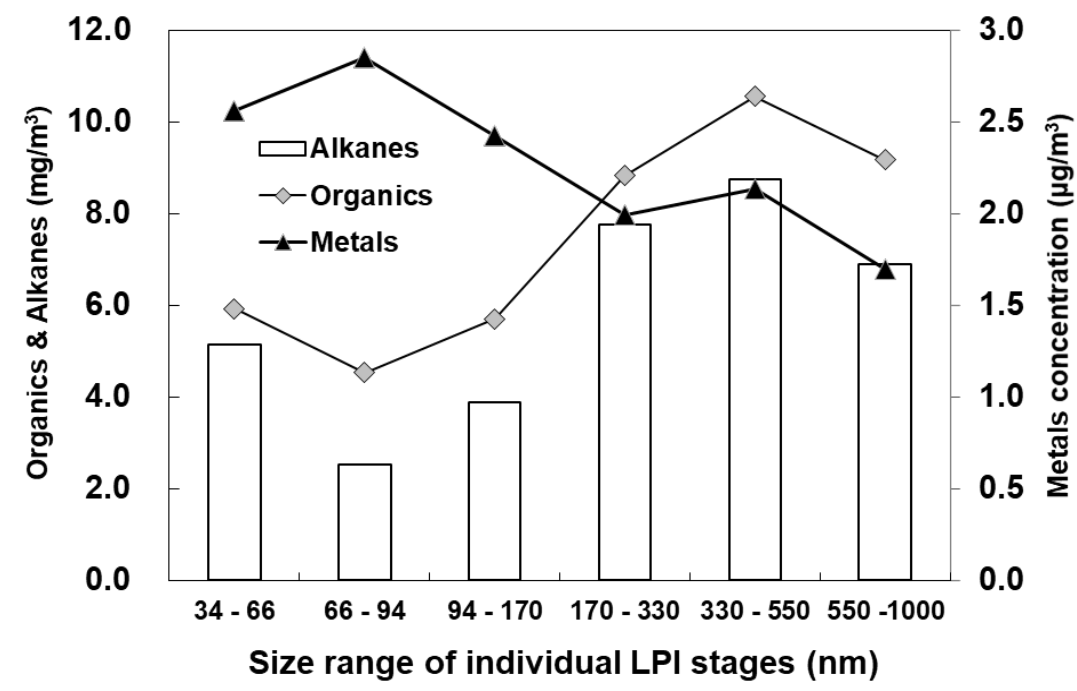

Fig. 4. Size distribution of alkanes, organics and metals in DEPs. All data points represent an average of triplicate measurements with a standard deviation of $0.92-1.30 \mathrm{mg} \mathrm{m}^{-3}$ for alkanes, $0.75-0.76 \mathrm{mg} \mathrm{m}^{-3}$ for organics and $0.21-0.33 \mu \mathrm{g} \mathrm{m}^{-3}$ for metals.
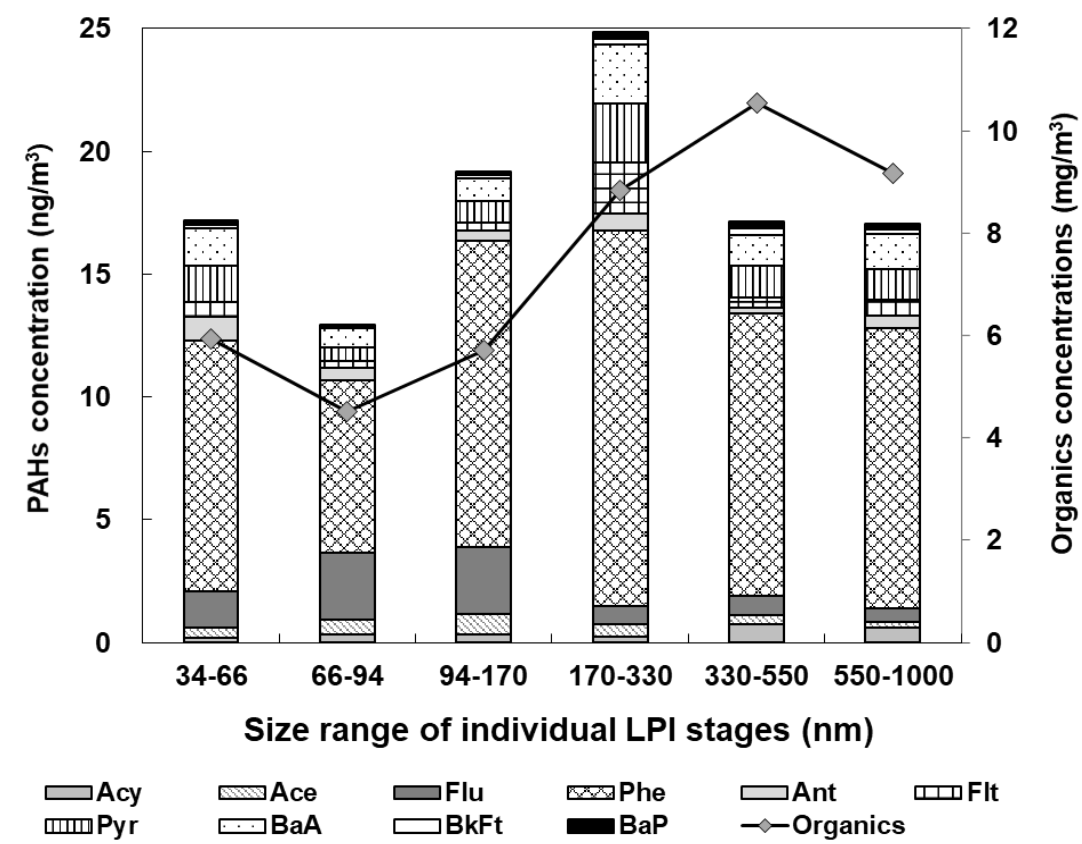

Fig. 5. Size distribution of identified PAHs and organics in DEPs. All data points represent an average of triplicate measurements with a standard deviation of $0.06-0.27 \mathrm{ng} \mathrm{m}^{-3}$ for acenaphthylene (Acy), $0.15-0.20 \mathrm{ng} \mathrm{m}^{-3}$ for acenaphthene (Ace), $0.12-0.73 \mathrm{ng} \mathrm{m}^{-3}$ for fluorene (Flu), 2.20-2.73 $\mathrm{ng} \mathrm{m}^{-3}$ for phenanthrene (Phe), $0.25-0.30 \mathrm{ng} \mathrm{m}^{-3}$ for anthracene (Ant), $0.15-0.89 \mathrm{ng} \mathrm{m}^{-3}$ for fluoranthene (Flt), 0.48-0.67 $\mathrm{ng} \mathrm{m}^{-3}$ for pyrene (Pyr), 0.39-0.61 $\mathrm{ng} \mathrm{m}^{-3}$ for benzo(a)anthracene (BaA), 0.02$0.05 \mathrm{ng} \mathrm{m}^{-3}$ for benzo(k)fluoranthene (BkFt) and $0.03-0.05 \mathrm{ng} \mathrm{m}^{-3}$ for benzo(a)pyrene (BaP), $0.75-0.76 \mathrm{mg} \mathrm{m}^{-3}$ for organics.

distributions of the organic compounds, Fig. 5 demonstrates that compare to the PAHs in the ultrafine DEPs (30.1 $\mathrm{ng} \mathrm{m}^{-3}$ ), the accumulation-mode DEPs emitted more PAHs $\left(78.2 \mathrm{ng} \mathrm{m}^{-3}\right)$. Three-ring phenanthrene shows the highest concentration among the identified PAHs in the DEPs $(<1 \mu \mathrm{m})$ under 13 driving modes. Other studies also shows similar results during light-duty diesel chassis dynamometer tests (Abrantes et al., 2004; Devos et al., 2006), medium-duty diesel engine dynamometer tests (Lim et al., 2015), and heavy-duty diesel mobile emission laboratory tests 
(Shah et al., 2005). In addition, at a bus station devoted only to diesel-powered vehicles, Phe was found to constitute more than $40 \%$ of the identified PAHs (Tavares et al., 2004). Moreover, due to the diesel exhaust particles were directly sampled on filters and analysed in this study (Fig. S1), Phe could be a significant composition in diesel emissions. Because Phe is postulated to be one of the prominent intermediates during growth of PAH and formation of soot (Marinov et al., 1998; Skjøth-Raamussen et al., 2004), which can be occurred through hydrogen abstraction acetylene addition (HACA) (Lombaert et al., 2006), polymerization including dominant condensation could be significant in the formation of DEPs in the accumulation mode.

To evaluate and identify the carcinogenicities of PAHs, the toxicity equivalent factor (TEF) method is considered to be more reliable and hence is commonly used (Delistraty, 1997; Halek et al., 2008; Froehner et al., 2010; Catino et al., 2017; Tan et al., 2017; Zhang et al., 2018; Zhou et al., 2019). Nisbet and LaGoy (1992) put forward the concept of TEF based on the toxicity of $\mathrm{BaP}$. BaP is considered to have the highest carcinogenicity of the 10 identified PAHs from the 13mode driving conditions and is usually used as a reference compound (Delistraty, 1997; Halek et al., 2008; Froehner et al., 2010; Catino et al., 2017; Tan et al., 2017; Zhang et al., 2018; Zhou et al., 2019) in order to derive TEF for PAHs. Table S1 summarizes the chemical parameters and TEF values of the 10 identified PAHs from the 13-mode driving conditions.

The toxicity equivalent quantity (TEQ) based on the TEF method is the classic way to evaluate the toxicities of particles. It is calculated as follows:

$\mathrm{TEQ}=\sum C_{i} \times \mathrm{TEF}_{i}$

where $C_{i}$ denotes the concentration of an individual $i \mathrm{PAH}$.

The size range of PAHs concentration by species, the size range of PAHs concentration by benzene ring number, and the size range of PAHs toxicity equivalent quantity by benzene ring number in diesel exhaust particulates deposited on the individual LPI stages were demonstrated in Figs. 5 and 6. Therefore, these figures could exhibit which size range of emitted diesel particles with significant PAHs have potential hazardous effect on human health.

Fig. 6(a) gives the concentrations of the PAHs in the size-segregated DEPs based on the number of benzene rings, and Fig. 6(b) depicts the size-segregated toxicity equivalent quantities of the PAHs by ring number.

Each size range of the PAHs was significantly dominated by 3-ring PAHs due to the high emission of Phe, and the six size-segregated concentrations and fraction ranges of the 3-ring PAHs ranged from $10.2-16.7 \mathrm{ng} \mathrm{m}^{-3}$ and $12.8-20.8 \%$, respectively. The size ranges of $170-330 \mathrm{~nm}$ in the accumulation mode and of 34-66 nm in the ultrafine mode showed the highest quantities of 3-ring and 4-ring PAHs in the DEPs. Notably, although the high molecular weight PAHs (4-ring and 5-ring PAHs) comprised only a small fraction of the total identified PAHs by mass, they comprised high fractions of the TEQ (Tan et al., 2017). The 5-ring PAHs had the highest TEQ, their total fraction exceeding 56.8\%, followed by the 4-ring PAHs (37.9\%). The TEQs of low-molecular weight (2-ring and 3-ring) PAHs were low. Similar to other studies (Halek et al., 2008; Froehner et al., 2010; Zhou et al., 2019), BaP showed the highest TEQ, and its fraction in the total TEQ exceeded $52.0 \%$, followed by $37.4 \%$ of $\mathrm{BaA}$ (4-ring) for the 13 -mode driving conditions. Two size ranges of TEQ peaks were observed for the ultrafine $(34-66 \mathrm{~nm}$ ) and accumulation modes (170$330 \mathrm{~nm}$ ) in the DEPs. This indicates that extremely high toxicities of the DEPs with regard to the PAHs were associated with both the smaller ultrafine (>66 nm) and the quasi-accumulation (170-330 $\mathrm{nm}$ ) size ranges.

Eight nitrogen-containing polycyclic aromatic compounds (NPACs) were identified in the DEPs $(<1 \mu \mathrm{m})$, with total concentrations ranging from $0.3-7.7 \mathrm{ng} \mathrm{m}^{-3}$ (Fig. 7).

Contrary to the trend observed for the quantified PAHs and total identifiable organic compounds, the identified NPACs were more abundant in the ultrafine mode, particularly in the peak size range of 66-94 $\mathrm{nm}$. The identified eight NPACs consist of four nitro arenes (nitro-PAHs) and four aza arenes (nitrogen-containing heterocyclic aromatic hydrocarbons), with total concentrations of 1.3-3.1 $\mathrm{ng} \mathrm{m}^{-3}$ and $0.3-7.3 \mathrm{ng} \mathrm{m}^{-3}$, respectively. The identified four nitro arenes were 4-nitrobiphenyl (4-Nbp), 9-nitroanthracene (9-Nant), 3-nitrophenanthrene (3-Nphe), and 7-nitrobenz[a]anthracene (7-NBaA), consisting of 1-3 aromatic rings. The four aza arenes were mainly composed of two and three aromatic rings, including 3-methylisoquinoline (3-MiQ), 7,8-benzoquinoline (7,8-BQ), 
(a)

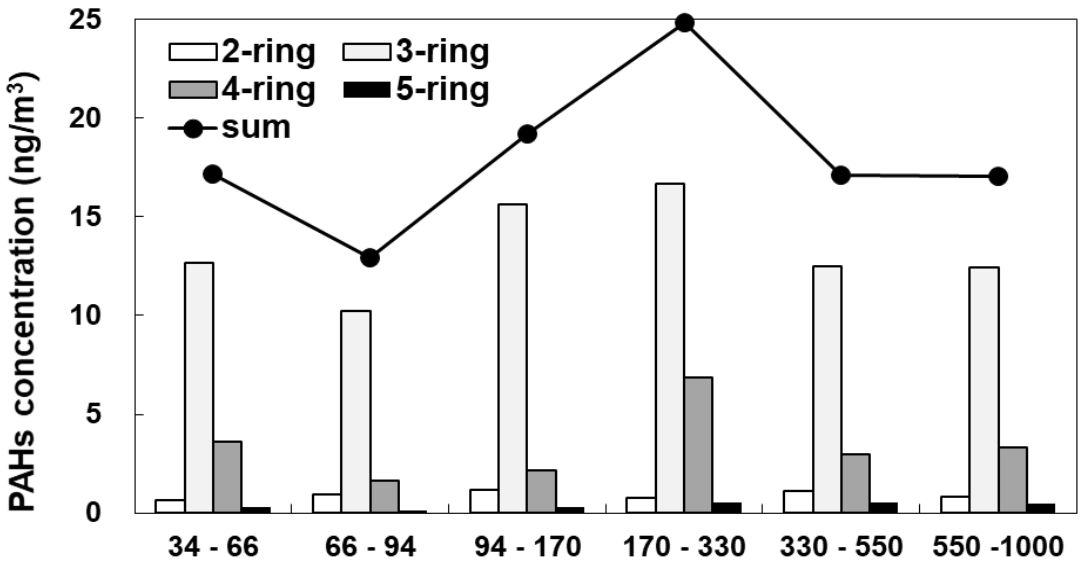

Size range of individual LPI stages $(\mathrm{nm})$

(b)

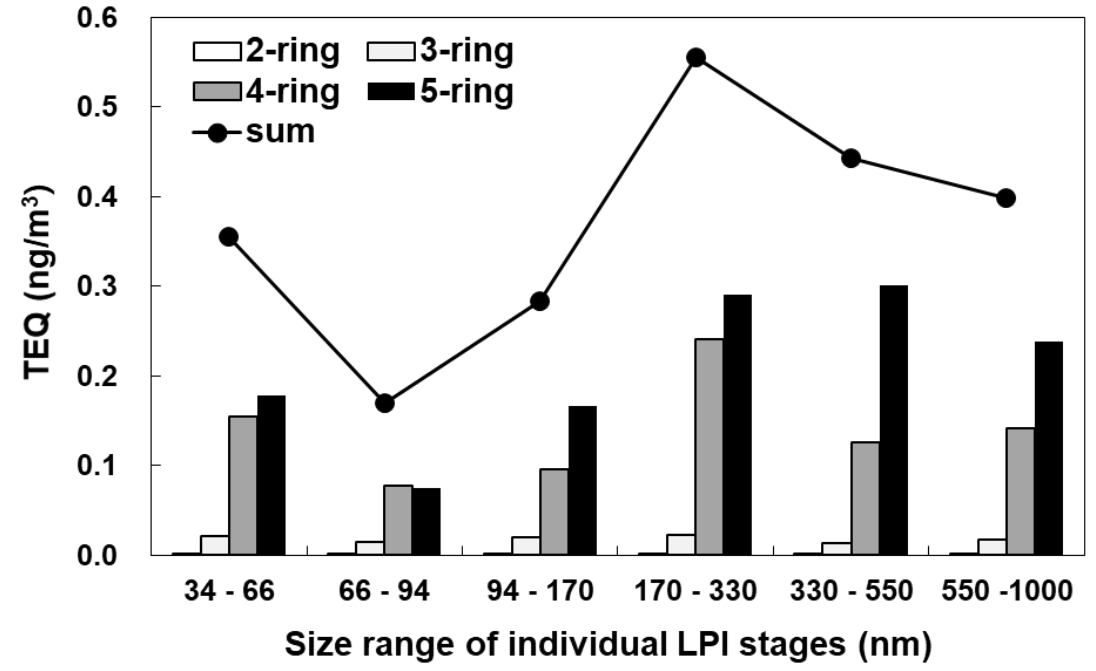

Fig. 6. Size distribution of PAHs concentration and TEQ by ring number in DEPs. All data points represent an average of triplicate measurements with a standard deviation of (a) $0.20-0.26 \mathrm{ng} \mathrm{m}^{-3}$ for 2-ring, 2.45-2.71 $\mathrm{ng} \mathrm{m}^{-3}$ for 3-ring, 1.02-2.16 $\mathrm{ng} \mathrm{m}^{-3}$ for 4-ring and 0.05-0.10 $\mathrm{ng} \mathrm{m}^{-3}$ for 5-ring, (b) 0.002-0.003 $\mathrm{ng} \mathrm{m}^{-3}$ for 2-ring, 0.003-0.004 $\mathrm{ng} \mathrm{m}^{-3}$ for 3-ring, 0.04-0.06 $\mathrm{ng} \mathrm{m}^{-3}$ for 4-ring and $0.03-0.06 \mathrm{ng} \mathrm{m}^{-3}$ for 5-ring.

acridine (Acr), and phenanthridine (Phd). Fig. 7 shows the size-segregated concentrations of individual NPACs in the DEPs $(<1 \mu \mathrm{m})$ for the 13-mode driving conditions. For each size range, 7,8-benzoquinoline (7,8-BQ) exhibited a concentration of $1.2-1.7 \mathrm{ng} \mathrm{m}^{-3}$, comprising $27-64 \%$ of the quantified NPACs. Moreover, $7,8-\mathrm{BQ}$ was accountable for $15 \%$ and $30 \%$ of the quantified NPACs in the ultrafine and accumulation mode DEPs, respectively.

Similar to 7,8-BQ, 3-nitrophenanthrene (3-Nphe) peaked in the ultrafine mode size range of 66-94 nm, its concentration being $2.9 \mathrm{ng} \mathrm{m}^{-3}$. However, no 3-Nphe was emitted in the accumulation mode range of $330-1000 \mathrm{~nm}$. It is worthwhile to note that the most predominant NPAC $(7,8$ benzoquinoline and 3-nitrophenanthrene) and $\mathrm{PAH}$ (Phe) have the same 3-aromatic-ring structure. Interestingly, this could be convincing evidence for the formation of nitro-PAHs (3-nitrophenanthrene) and aza arenes (7,8-benzoquinoline) through respective nitration and pyrosynthesis between the $\mathrm{PAH}$ radicals and $\mathrm{NO}_{x}$ radicals. (Williams et al., 1986, 1989; Rogge et al., 1993; Wiersum, 1996; Murahashi et al., 2003; Ghigo et al., 2006). Notably, Upham et al. (1998), Rummel et al. (1999) and Catterall et al. (2001) indicated that a bay-region-like structure of aromatic species can induce more mutagenicity and has higher cancer leading probability compared with linear structured PAHs. Therefore, large amounts of Phe, 7,8-BQ and 3-Nphe in the DEPs, which constitute the bayregion-like structure, could pose more toxicity to humans (Lim et al., 2015). In particular, the 

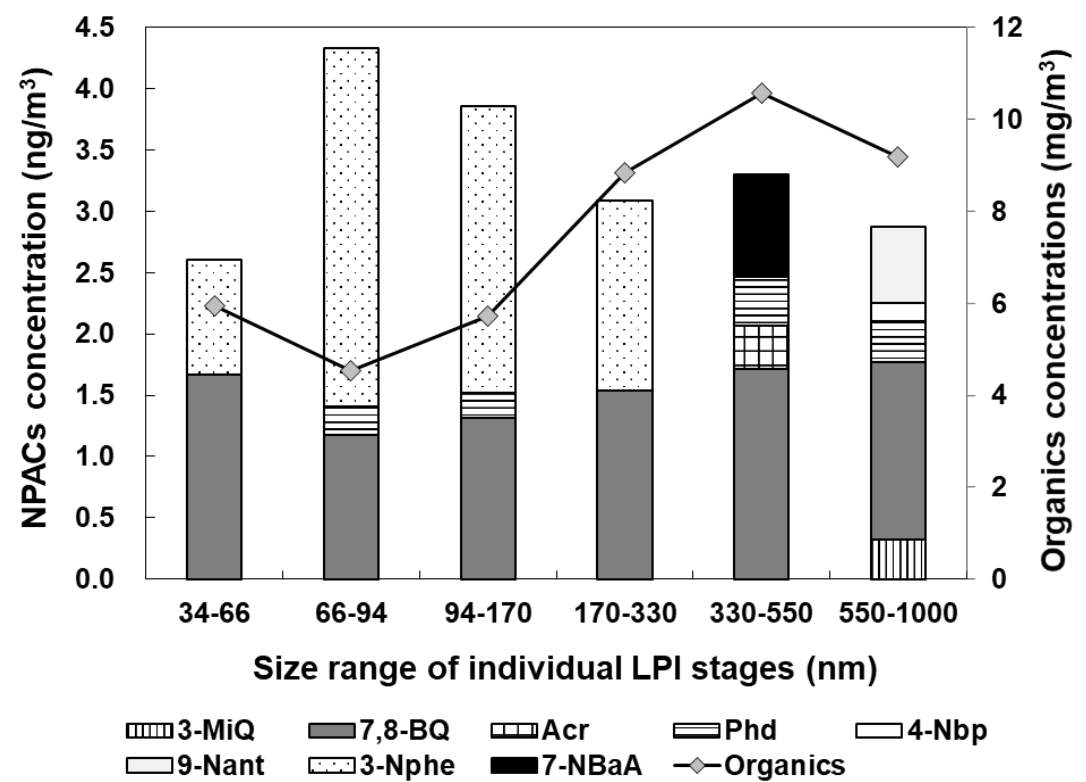

Fig. 7. Size distribution of identified NPACs and organics in DEPs. All data points represent an average of triplicate measurements with a standard deviation of $0.13-0.25 \mathrm{ng} \mathrm{m}^{-3}$ for 3methylisoquinoline (3-MiQ), 0.00-0.20 $\mathrm{ng} \mathrm{m}^{-3}$ for 7,8-benzoquinoline (7,8-BQ), 0.12-0.21 $\mathrm{ng} \mathrm{m}^{-3}$ for acridine (Acr), $0.00-0.08 \mathrm{ng} \mathrm{m}^{-3}$ for phenanthridine (Phd), 0.00-0.36 $\mathrm{ng} \mathrm{m}^{-3}$ for 4-nitrobiphenyl (4-Nbp), 0.89-1.02 $\mathrm{ng} \mathrm{m}^{-3}$ for 9-nitroanthracene (9-Nant), 0.00-0.48 $\mathrm{ng} \mathrm{m}^{-3}$ for 3-nitrophenanthrene (3-Nphe) and 0.21-0.90 $\mathrm{ng} \mathrm{m}^{-3}$ for 7-nitrobenz[a]anthracene (7-NBaA).

ultrafine ranges of 7,8-BQ and 3-Nphe are expected to be more harmful than the larger particles (Ruckerl et al., 2011; Bakand et al., 2012) as the smaller UFPs can be deposited deeply into the human lung (Oberdörster et al., 2004; Geiser and Kreyling, 2010).

\section{CONCLUSIONS}

To investigate the effect of driving conditions on DEPs, size-segregated carbonaceous substances, metals, and organic compounds in DEPs were characterized using a medium-duty diesel engine dynamometer with the 13-mode test. In detail, most organic carbon and elemental carbon were observed in the accumulation mode $(330-550 \mathrm{~nm})$. The effect of a more and higher engine load portion during 13-mode driving test demonstrated the shifting of the EC and OC peak concentrations toward a larger-size range (above $100 \mathrm{~nm}$ ) due to higher unburned hydrocarbon emissions and more lubricating oil consumption. However, another peak (34-66 nm) of the OC/EC ratio was noted because of the larger ultrafine particles from the idle and low loading conditions. Larger surface per mass ratio, leading to the adsorption of semi-volatile and volatile organic compounds onto smaller particles, could contribute to form the more small size particles (below $100 \mathrm{~nm}$ ) leading to higher OC fractions and OC/EC ratios.

It is worthwhile to note that the more emitted metal contents within the range of 34-170 nm could have been catalyzed by oxidation of larger size of DEPs including participation in nucleation at high temperatures under full engine load. Consequently, the sum of metal concentration increased (decreased) in individual size ranges, the EC and OC concentrations decreased (increased) concurrently. The 13-mode driving conditions exhibited the more amount of smaller size metals within the range of 34-170 nm including the highest Fe emission (57-66\% of the quantified metals), because Fe was the major component in the tested diesel fuel and lubricant in this study. Although the quantified amounts of related toxic $\mathrm{Pb}, \mathrm{As}$, and $\mathrm{Cd}$ were less than $0.03-2.5 \%$ in the DEPs, their cumulative fractions for the ultrafine mode exceeded $50 \%$, implying more adverse health effect due to deeper invasion of ultrafine toxic metal into human respiratory system.

Abundant organic compounds (76.6\%) including alkanes (67.0\%) were emitted in the range of 170-1000 $\mathrm{nm}$. The relationship between organic contents and metal concentrations exhibited a 
trend similar to that for EC and OC contents versus metal concentrations due to the catalyzing oxidation of soot and organic compounds by metals in the engine combustion chamber. Similar to the size distributions of the organic compounds, more than $70 \%$ of the identified PAHs were emitted in the more than $94 \mathrm{~nm}$ size range, and the concentration of Phe was the highest for the 13-mode test. The TEF method was used to evaluate the carcinogenicities of the PAHs, and two significant size ranges of the TEQ peaks for the ultrafine (34-66 nm) and accumulation (170$330 \mathrm{~nm}$ ) modes were identified in the DEPs. Notably, the PAHs concentration by species, and toxicity equivalent quantity by benzene ring number demonstrated two peak concentrations in the size range of 34-66 nm and 170-330 nm. This indicates that extremely high toxicities of the DEPs with regard to the PAHs were associated with both the smaller ultrafine $(>66 \mathrm{~nm})$ and the quasi-accumulation (170-330 $\mathrm{nm}$ ) size ranges.

Interestingly, contrary to the trends noted for the PAHs and organic compounds, the identifiable NPACs were more abundant in the ultrafine mode, and thus, the overall DEPs toxicity potential was higher due to the fact that UFPs can be deposited with high efficiency throughout the human respiratory tract.

\section{ACKNOWLEDGMENTS}

The authors gratefully acknowledge the National Institute of Environmental Research (NIER) of the Ministry of Environment, Republic of Korea, for funding and supporting this work under the Environmental Research \& Development Program (NIER-2018-01-01-091).

\section{SUPPLEMENTARY MATERIAL}

Supplementary data associated with this article can be found in the online version at https://doi.org/10.4209/aaqr.200356

\section{REFERENCES}

Abrantes, R., Assunção, J.V., Pesquero, C.R. (2004). Emissions of polycyclic aromatic hydrocarbons from light-duty diesel vehicles exhaust. Atmos. Environ. 38, 1631-1640. https://doi.org/10.10 16/j.atmosenv.2003.11.012

Ahmed, M., Guo, X., Zhao, X.M. (2016). Determination and analysis of trace metals and surfactant in air particulate matter during biomass burning haze episode in Malaysia. Atmos. Environ. 141, 219-229. https://doi.org/10.1016/j.atmosenv.2016.06.066

Bakand, S., Hayes, A., Dechsakulthorn, F. (2012). Nanoparticles: A review of particle toxicology following inhalation exposure. Inhalation Toxicol. 24, 125-135. https://doi.org/10.3109/0895 8378.2010.642021

Banerjee, T., Christian, R.A. (2019). Effect of operating conditions and speed on nanoparticle emissions from diesel and gasoline driven light duty vehicles. Atmos. Pollut. Res. 10, 18521865. https://doi.org/10.1016/j.apr.2019.07.017

Cao, X., Hao, X., Shen, X., Jiang, X., Wu, B., Yao, Z. (2017). Emission characteristics of polycyclic aromatic hydrocarbons and nitro-polycyclic aromatic hydrocarbons from diesel trucks based on on-road measurements. Atmos. Environ. 148, 190-196. https://doi.org/10.1016/j.atmosen v.2016.10.040

Catino, S., Tutino, M., Ruggieri, S., Marinaccio, C., Giua, R., Gennaro, G., Corsi, P., Assennato, G., Ribatti, D. (2017). Angiogenic activity in vivo of the particulate matter ( $\left.\mathrm{PM}_{10}\right)$. Ecotoxicol. Environ. Saf. 140, 156-161. https://doi.org/10.1016/j.ecoenv.2017.02.036

Catterall, F.S., Coombs, M.M., Ioannides, C., Sepiol, J.J., Wilson, J. (2001). Mutagenicity of bayregion amino-substituted cyclopenta[a]phenanthrenes and 2- and 5-aminochrysene. Mutat. Res. 492, 7-11. https://doi.org/10.1016/S1383-5718(01)00144-9

Chian, H.L., Lai, Y.M., Chang, S.Y. (2012). Pollutant constituents of exhaust emitted from lightduty diesel vehicles. Atmos. Environ. 47, 399-406. https://doi.org/10.1016/j.atmosenv.2011.1 0.045 
Chuang, H.C., Fan, C.W., Chen, K.Y., Chang-Chien, G.P., Chan, C.C. (2012). Vasoactive alteration and inflammation induced by polycyclic aromatic hydrocarbons and trace metals of vehicle exhaust particles. Toxicol. Lett. 214, 131-136. https://doi.org/10.1016/j.toxlet.2012.08.012

Delistraty, D. (1997). Toxic equivalency factor approach for risk assessment of ploycyclic aromatic hydrocarbons. Toxicol. Environ. Chem. 64, 81-108. https://doi.org/10.1080/02772249709358 542

Devos, O., Combet, E., Tassel, P., Paturel, L. (2006). Exhaust emissions of PAHs of passenger cars. Polycyclic Aromat. Compd. 26, 69-78. https://doi.org/10.1080/10406630500519346

DieselNet (2019a). Emission test cycles: ECE 15 + EUDC/NEDC. https://www.dieselnet.com/stand ards/cycles/ece_eudc.php (accessed 17 May 2019).

DieselNet (2019b). Emission test cycles: Heavy-duty FTP transient cycle. https://www.dieselnet.c om/standards/cycles/ftp_trans.php (accessed 17 May 2019).

DieselNET (2019c). Emission test cycles: European stationary cycles. https://www.dieselnet.com/ standards/cycles/esc.php (accessed 26 August 2019).

Du, J., Sun, W., Guo, L., Xiao, S., Tan, M., Li, G., Fan, L. (2015). Experimental study on fuel economies and emissions of direct-injection premixed combustion engine fueled with gasoline/diesel blends. Energy Convers. Manage. 100, 300-309. https://doi.org/10.1016/j.enconman.2015.04.076

Dwivedi, D., Agarwal, A.K., Sharma, M. (2006). Particulate emission characterization of a biodiesel vs diesel-fueled compression ignition transport engine: A comparative study. Atmos. Environ. 40, 5586-5595. https://doi.org/10.1016/j.atmosenv.2006.05.005

European Automobile Manufacture's Association (2015). Diesel penetration. 2014. http://www.a cea.be/statistics/tag/category/dieselpenetration (accessed 3 March 2015).

Froehner, S., Maceno, M., Machado, K.S., Malheiros, A. (2010). Polycycloc aromatic hydrocarbons (PAHs) in airborne particulate matter in Curitiba, Brazil and benzo(a)pyrene toxic equivalency factors (TEFs). J. Environ. Sci. Health., Part A 45, 1347-1352. https://doi.org/10.1080/1093452 9.2010.500889

Geiser, M., Kreyling, W. (2010). Deposition and biokinetics of inhaled nanoparticles. Part. Fibre Toxicol. 7, 2. https://doi.org/10.1186/1743-8977-7-2

Geller, M.D., Ntziachristos, L., Mamakos, A., Samaras, Z., Schmitz, D.A., Froines, J.R., Sioutas, C. (2006). Physicochemical and redox characteristics of particulate matter (PM) emitted from gasoline and diesel passenger cars. Atmos. Environ. 40, 6988-7004. https://doi.org/10.1016/j. atmosenv.2006.06.018

Ghigo, G., Causà M., Maranzana, A., Tonachini, G. (2006). Aromatic hydrocarbon nitration under tropospheric and combustion conditions. A theoretical mechanistic study. J. Phys. Chem. A 110, 13270-13282. https://doi.org/10.1021/jp064459c

Golokhvast, K., Chernyshev, V.V., Chaika, V.V., Ugay, S.M., Zelinskaya, E.V., Tsatsakis, A.M. Karakitsios, S.P., Sarigiannis, D.A. (2015). Size-segrated emissions and metal content of vehicleemitted particles as a function of mileage: Implications to population exposure. Environ. Res. 142, 479-485. https://doi.org/10.1016/j.envres.2015.07.018

Halek, F., Nabi, G., Kavousi, A. (2008). Polycyclic aromatic hydrocarbons study and toxic equivalency factor (TEFs) in Tehran, IRAN. Environ. Monit. Assess. 143, 303-311. https://doi.org/10.1007/s10661-007-9983-9

Hao, Y., Gao, C., Deng, S., Yuan, M., Song, W., Lu, Z., Qiu, Z. (2019). Chemical characterization of $\mathrm{PM}_{2.5}$ emitted from motor vehicles powered by diesel, gasoline, natural gas and methanol fuel. Sci. Total Environ. 674, 128-139. https://doi.org/10.1016/j.scitotenv.2019.03.410

Jian, Y., Yang, J., Cocker III D., Karavalakis, G., Johnson, K.C., Durbi, T.D. (2018). Characterizing emission rates of regulated pollutants from model year $2012+$ heavy-duty diesel vehicles equipped with DPF and SCR systems. Sci. Total Environ. 619-620, 765-771. https://doi.org/10. 1016/j.scitotenv.2017.11.120

Jung, S., Mun, S., Chung, T., Kim, S., Seo, S., Kim, I., Hong, H., Chong, H., Sung, K., Kim, J., Hong, Y. (2019). Emission characteristics of regulated and unregulated air pollutants from heavy duty diesel trucks and buses. Aerosol Air Qual. Res. 19: 431-442. https://doi.org/10.4209/aaqr.201 8.05.0195

Kim, S.H., Fletcher, R.A., Zachariah, M.R. (2005). Understanding the difference in oxidative properties between flame and diesel soot nanoparticles: The role of metals. Environ. Sci. Technol. 39, 4021-4026. https://doi.org/10.1021/es048828z 
Kontses, A., Triantafyllopous, G., Ntziachristos, I., Samaras, Z. (2020). Particle number (PN) emissions from gasoline, diesel, LPG, CNG and hybrid-electric light vehicles under real-world driving conditions. Atmos. Environ. 222, 117126. https://doi.org/10.1016/j.atmosenv.2019.117126

Kuo, C.Y., Chien, P.S., Kuo, W.C., Wei, C.T., Rau, J.Y. (2013). Comparison of polycyclic aromatic hydrocarbon emissions on gasoline- and diesel-dominated routes. Environ. Monit. Assess. 185, 5749-5761. https://doi.org/10.1007/s10661-012-2981-6

Lee, H., Hwang-Bo, H., Ji, S.Y., Kim, M.Y., Kim, S.Y., Park, C., Hong, S.H., Kim, G.-Y., Song, K.S., Hyun, J.W., Choi, Y.H. (2020). Diesel particulate matter2.5 promotes epithelial-mesenchymal transition of human retinal pigment epithelial cells via generation of reactive oxygen species. Environ. Pollut. 262, 114301. https://doi.org/10.1016/j.envpol.2020.114301

Li, X., Xu, Z., Guan C., Huang, Z. (2014). Particle size distributions and OC, EC emissions from a diesel engine with the application of in-cylinder emission control strategies. Fuel 121, 20-26. https://doi.org/10.1016/j.fuel.2013.12.031

Li, X., Dallmann, T.R., May, A.A., Stanier, C.O., Griesshop, A.P., Lipsky, E.M., Robinson, A.L., Presto, A.A. (2018). Size distribution of vehicle emitted primary particles measured in a traffic tunnel. Atmos. Environ. 191, 9-18. https://doi.org/10.1016/j.atmosenv.2018.07.052

Liati, A., Schreiber, D., Dasilva, Y.A.R., Eggenschwiler, P.D. (2018). Ultrafine particle emissions from modern gasoline and diesel vehicles: An electron microscopic perspective. Environ. Pollut. 239, 661-669. https://doi.org/10.1016/j.envpol.2018.04.081

Lim, J., Yu, L.E., Kostetski, Y.Y., Lim, C., Ryu, J., Kim, J. (2008). Effects of driving conditions on diesel exhaust particulates. J. Air Waste Manage. Assoc. 58, 1077-1085. https://doi.org/10.3155/10 47-3289.58.8.1077

Lim, J., Lim, C., Yu, L.E. (2009). Composition and size distribution of metals in diesel exhaust particulates. J. Environ. Monit. 11, 1614-1621. https://doi.org/10.1039/B822514A

Lim, J., Lim, C., Kim, S., Hong, J. (2015). Characterizations of organic compounds in diesel exhaust particulates. J. Environ. Sci. 34, 171-183. https://doi.org/10.1016/j.jes.2015.03.013

Lin, Y.C., Li, Y.C., Amesho, K.T.T., Chou, F.C., Cheng, P.C. (2019). Characterization and quantification of $\mathrm{PM}_{2.5}$ emissions and $\mathrm{PAH}$ concentration in $\mathrm{PM}_{2.5}$ from the exhausts of diesel vehicles with various accumulated mileages. Sci. Total Environ. 660, 188-198. https://doi.org/ 10.1016/j.scitotenv.2019.01.007

Lombaert, K., Moyne, L., Maleissye, J.T., Amouroux, J. (2006). Experimental study of PAH in engine soot by isotopic tracing. Combust. Sci. Technol. 178, 707-728. https://doi.org/10.1080/ 00102200500248417

Lund, M.T., Berntsen, T.K., Heyes, C., Klimont, Z., Samset, B.H. (2014). Globaland regional climate impacts of black carbon and co-emitted species from the on-road diesel sector. Atmos. Environ. 98, 50-58. https://doi.org/10.1016/j.atmosenv.2014.08.033

Magnani, N.D., Marchini, T., Garcés, M., Mebert, A., Cáceres, L., Diaz, L., Desimone, M., Evelson, P. (2016). Role of transition metals present in air particulate matter on lung oxygen metabolism. Int. J. Biochem. Cell B. 81, 419-426. https://doi.org/10.1016/j.biocel.2016.10.009

Marinov, N.M., Pitz, W.J., Westbrook, C.K., Vincitore, A.M., Castaldi, M.J., Senkan, S.M., Melius, C.F. (1998). Aromatic and polycyclic aromatic hydrocarbon formation in a laminar premixed nbutane flame. Combust. Flame 114, 192-213. https://doi.org/10.1016/S0010-2180(97)00275-7

Moretti, S., Smets, W., Hofman, J., Mubiana, K.V., Oerlemans, E., Vandenheuvel, D., Samson, R., Blust, R., Lebeer, S. (2019). Human inflammatory response of endotoxin affected by particulate matter-bound transition metals. Environ. Pollut. 244, 118-126. https://doi.org/10.1016/j.envp ol.2018.09.148

Murahashi, T., Tsuruga, F., Sasaki, S. (2003). An automatic method for the determination of carcinogenic 1-nitropyrene in extracts from automobile exhaust particulate matter. Analyst 128, 1346-1351. https://doi.org/10.1039/B308207E

Ni, P., Bai, L., Wang, X., Li, R. (2018). Characteristics of evolution of in-cylinder soot particle size and number density in a diesel engine. Fuel 228, 215-225. https://doi.org/10.1016/j.fuel.2018. 04.158

Nisbet, I.C.T., LaGoy, P.K. (1992). Toxic equivalency factors (TEFs) for polycyclic aromatic hydrocarbons (PAHs). Regul. Toxicol. Pharm. 16, 290-300. https://doi.org/10.1016/02732300(92)90009-X

Oanh, N.T.K., Thiansathit, W., Bond, T.C., Subramanian, R., Winijkul, E., Paw-armart, I. (2010). 
Compositional characterization of $\mathrm{PM}_{2.5}$ emitted from in-use diesel vehicles. Atmos. Environ. 44, 15-22. https://doi.org/10.1016/j.atmosenv.2009.10.005

Oberdörster, G., Sharp, Z., Atudorei, V., Elder, A., Gelein, R., Kreyling, W., Cox, C. (2004). Translocation of inhaled ultrafine particles to the brain. Inhalation Toxicol. 16, 437-445. https://doi.org/10.1080/08958370490439597

Oetari, P.S., Hadi, S.P., Huboyo, H.S. (2019). Trace elements in fine and coarse particles emitted from coal-fired power plants with different air pollution control systems. J. Environ. Manage. 250, 109497. https://doi.org/10.1016/j.jenvman.2019.109497

Onay, T.T., Copty, N.K., Gökçe, H.B., Aydın-Sarıkurt, D., Mumcu, M., Arıoğlu, E. (2019). Air quqlity impact assessment for the Eurasia Tunnel in Istanbul, Turkey. Environ. Monit. Assess. 191, 195. https://doi.org/10.1007/s10661-019-7340-4

Pan, C.J., Schmitz, D., Cho, A.K., Froines, J., Fukuto, M. (2004). Inherent redox properties of diesel exhaust particles: Catalysis of the generation of reactive oxygen species by biological reductants. Toxicol. Sci. 81, 225-232. https://doi.org/10.1093/toxsci/kfh199

Pěnčíková, K., Ciganek, M., Neča, J., Illés, P., Dvořák, Z., Vondráček, J., Machala, M. (2019). Modulation of endocrine nuclear receptor activities by polyaromatic compounds present in fractionated extracts of diesel exhaust particles. Sci. Total Environ. 677, 626-636. https://doi.org/10.1016/j.scitotenv.2019.04.390

Reijnders, J., Boot, M., Goey, P. (2018). Particle nucleation-accumulation mode trade-off: A second diesel dilemma? J. Aerosol Sci. 124, 95-111. https://doi.org/10.1016/j.jaerosci.2018.06.013

Riddle, S.G., Robert, M.A., Jakobert, C., Hannigan, M.P., Kleeman, M.J. (2007). Size distribution of trace organic species emitted from heavy-duty diesel vehicles. Environ. Sci. Technol. 41, 19621969. https://doi.org/10.1021/es0617183

Rogge, W.F., Hlldemann, L.M., Mazurek, M.A., Cass, G.R. (1993). Sources of fine organic aerosol. 5. Natural gas home appliances. Environ. Sci. Technol. 27, 2736-2744. https://doi.org/10.102 1/es00049a012

Rönkkö, T., Pirjola, L., Ntziachristos, L., Heikkilä, J., Karjalainen, P., Hillamo, R., Keskinen, J. (2014). Vehicle engines produce exhaust nanoparticles even when not fueled. Environ. Sci. Technol. 48, 2043-2050. https://doi.org/10.1021/es405687m

Ruckerl, R., Schneider, A., Breitner, S., Cyrys, J., Peters, A. (2011). Health effects of particulate air pollution: A review of epidemiological evidence. Inhalation Toxicol. 23, 555-592. https://doi.org/10.3109/08958378.2011.593587

Rummel, A.M., Trosko, J.E., Wilson, M.R., Upham, B.L. (1999). Polycyclic aromatic hydrocarbons with bay-like regions inhibited gap junctional intercellular communication and stimulated MAPK activity. Toxicol. Sci. 49, 232-240. https://doi.org/10.1093/toxsci/49.2.232

Schneider, J., Hock, N., Weimer, S., Borrmann, S. (2005). Nucleation particles in diesel exhaust: Composition inferred from in situ mass spectrometric analysis. Environ. Sci. Technol. 39, 61536161. https://doi.org/10.1021/es049427m

Shah, S.D., Ogunyoku, T., Miller, J.W., Cocker III, D.R. (2005). On-road emission rates of PAH and n-alkane compounds from heavy-duty diesel vehicles. Environ. Sci. Technol. 39, 5276-5284. https://doi.org/10.1021/es048086+

Shuster-Meiseles T., Shafer, M.M., Heo, J., Pardo, M., Antkiewicz, D.S., Schauer, J.J., Rudich, A., Rudich, Y. (2016). ROS-generating/ARE-activating capacity of metals in roadway particulate matter deposited in urban environment. Environ. Res. 146, 252-262. https://doi.org/10.1016/ j.envres.2016.01.009

Sirignano, M., Conturso, M., Magno, A., Di lorio, S., Mancaruso, E., Vaglieco, B.M., D’Anna, A. (2018). Evidence of sub-10 nm particles emitted from a small-size diesel engine. Exp. Therm Fluid Sci. 95, 60-64. https://doi.org/10.1016/j.expthermflusci.2018.01.031

Skjøth-Raamussen, M.S., Glarborg, P., Østberg, M., Johannessen, J.T., Livbjerg, H., Jensen, A.D., Christensen, T.S. (2004). Formation of polycyclic aromatic hydrocarbons and soot in fuel-rich oxidation of methane in a laminar flow reactor. Combust. Flame 136, 91-128. https://doi.org/ 10.1016/j.combustflame.2003.09.011

Snow, S.J., McGee, J., Miller, D.B., Bass, V., Schladweiler, M.C., Thomas, R.F. (2014). Inhaled diesel emissions generated with cerium oxide nanoparticle fuel additive induce adverse pulmonary and systematic effects. Toxicol. Sci. 142, 403-417. https://doi.org/10.1093/toxsci/kfu187

Tan, P., Zhong, Y., Hu, Z., Lou, D. (2017). Size distributions, PAHs and inorganic ions of exhaust 
particles from a heavy duty diesel engine using B20 biodiesel with different exhaust aftertreatments. Energy 141, 898-906. https://doi.org/10.1016/j.energy.2017.09.122

Tavares, Jr. M., Pinto, J.P., Souza, A.L., Scarminio, I.S., Solci, M.C. (2004). Emission of polycyclic aromatic hydrocarbons from diesel engine in a bus station, Londrina, Brazil. Atmos. Environ. 38, 5039-5044. https://doi.org/10.1016/j.atmosenv.2004.06.020

Upham, B.L., Weis, L.M., Trosko, J.E. (1998). Modulated gap junctional intercellular communication as a biomarker of PAH epigenetic toxicity: structure-function relationship. Environ. Health Perspect. 106, 975-981. https://doi.org/10.1289/ehp.98106s4975

Wang, C., Meng, Z., Yao, P., Zhang L., Wang Z., Lv Y., Tian Y., Feng Y. (2019). Sources-specific carcinogenicity and mutagenicity of $\mathrm{PM}_{2.5}$-bound PAHs in Beijing, China: Variations of contributions under diverse anthropogenic activities. Ecotoxicol. Environ. Saf. 183, 109552. https://doi.org/10.1016/j.ecoenv.2019.109552

Wiersum, U.E. (1996). The formation of polycyclic aromatic, fullerenes and soot in combustion. The mechanism and the environmental connection. Polycycl. Aromat. Comp. 11, 291-300. https://doi.org/10.1080/10406639608544678

Williams, P.T., Bartle, K.D., Andrew, G.E. (1986). The relation between polycyclic aromatic compounds in diesel fuels and exhaust particulates. Fuel 65, 1150-1157. https://doi.org/10.10 16/0016-2361(86)90184-5

Williams, P.T., Abbass, M.K., Andrews, G.E. (1989). Diesel particulate emissions: The role of unburned fuel. Combust. Flame 75, 1-24. https://doi.org/10.1016/0010-2180(89)90083-7

Wu, B., Shen, X., Cao, X., Yao, Z., Wu, Y. (2016). Characterization of the chemical composition of $\mathrm{PM}_{2.5}$ emitted from on-road China III and China IV diesel trucks in Beijing, China. Sci. Total Environ. 551-552, 579-589. https://doi.org/10.1016/j.scitotenv.2016.02.048

Xu, P., Chen, Y., He, S., Chen, W., Wu, L., Xu, D., Chen, Z., Wang, X., Lou, X. (2020). A follow-up study on the characterization and health risk assessment of heavy metals in ambient air particles emitted from a municipal waste incinerator in Zhejiang, China. Chemosphere 246, 125777. https://doi.org/10.1016/j.chemosphere.2019.125777

Yang, H.H., Dhital, N.B., Wang, L.C., Hsieh, Y.S., Lee, K.T., Hsu, Y.T., Huang, S.C. (2019). Chemical characterization of fine particulate matter in gasoline and diesel vehicle exhaust. Aerosol Air Qual. Res. 19, 1439-1449. https://doi.org/10.4209/aaqr.2019.04.0191

Zhang, Z.H., Balasubramanian, R. (2015). Effects of oxygenated fuel blends on carbonaceous particulate composition and particle size distributions from a stationary diesel engine. Fuel 141, 1-8. https://doi.org/10.1016/j.fuel.2014.10.023

Zhang, Z.H., Balasubramanian, R. (2018). Effects of oxygenated fuel blends on the composition of size-segregated engine-out diesel particulate emissions and on the toxicity of quasi-ultrafine particles. Fuel 215, 161-170. https://doi.org/10.1016/j.fuel.2017.10.097

Zhao, T., Yang, L., Huang, Q., Zhang, Y., Bie, S., Li, J., Zhang, W., Duan, S., Gao, H., Wang, W. (2020). $\mathrm{PM}_{2.5}$-bound polycyclic aromatic hydrocarbons (PAHs) and their derivates (nitrated-PAHs and oxygenated-PAHs) in a road tunnel located in Qingdao, China: Characteristics, sources and emission factors. Sci. Total Environ. 720, 137521. https://doi.org/10.1016/j.scitotenv.2020.13 7521

Zhou, S., Zhou, J., Zhu, Y. (2019). Chemical composition and size distribution of particulate matters from marine diesel engines with different fuel oils. Fuel 235, 972-983. https://doi.org/ 10.1016/j.fuel.2018.08.080 